BBA 46 I 50

\title{
THE OXIDATION-REDUCTION POTENTIALS OF PARSLEY FERREDOXIN AND ITS SELENIUM-CONTAINING HOMOLOG
}

\author{
JAMES A. FEE *, STEPHEN G. MAYHEW AND GRAHAM PALMER \\ Biophysics Research Division, Institute of Science and Technology and the Department of Biological \\ Chemistry, University of Michigan, Ann Arbor, Mich. 78 To5 (U.S.A.)
}

(Received March 2nd, I97I)

SUMMARY

We have measured the oxidation-reduction potential of parsley ferredoxin and its derivative in which the two atoms of labile sulfide have been replaced by selenide. The values are $-0.4 \mathrm{I} 6 \mathrm{~V}\left(25^{\circ}, \mathrm{pH} 7.94\right)$ and $-0.378 \mathrm{~V}\left(25^{\circ}, \mathrm{pH} 8 . \mathrm{I}_{4}\right)$ for the sulfur and selenium derivatives, respectively. Both values show a slight negative dependence on $\mathrm{pH}$.

The ferredoxins of both plant and bacterial origin are noted for their unusually low redox potentials. The chloroplast proteins accept only a single electron from strong reducing agents such as dithionite and the viologen dyes while the bacterial ferredoxins accept two electrons apparently into two distinct centers (ref. I contains a compilation of data on stoichiometry, $c f$. ref. 2).

It is now known that the chloroplast ferredoxins ${ }^{3,4}$, adrenodoxin ${ }^{5,6}$, and putidaredoxin ${ }^{6,7}$ contain a single active center which consists, in part, of 2 atoms of iron and 2 atoms of labile sulfur. Recently, the labile sulfur of parsley ferredoxin has been replaced by selenium and the resulting protein found to be biologically active, to accept only a single electron from dithionite, and to possess spectroscopic properties very similar to the native protein ${ }^{3}$. We report here the results of our studies on the redox potentials of parsley ferredoxin and the derivative in which both atoms of labile sulfur are replaced with selenium.

Parsley ferredoxin was prepared as previously described ${ }^{3}$, while the selenium protein was prepared as follows: a three compartment anaerobic vessel containing, in the first compartment apoprotein prepared by trichloroacetic acid precipitation and a 20-fold molar excess of dithiothreitol, in the second a 3-fold molar excess of ferric citrate, and in the third compartment a 3 -fold molar excess of elemental selenium, was carefully evacuated and filled with hydrogen gas. The sidearm containing the selenium was then gently heated with a flame about the size of that from a match. In this way it was possible to reduce all of the Se(o) to Se (-- II) and transfer it to the

* Present address: Department of Chomistry, Rensselaer Polytechnic Institute, Troy, N.Y. (U.S.A.). 
protein solution as $\mathrm{H}_{2} \mathrm{Se}$. The iron solution was then mixed in, completing the reaction mixture. The remainder of the preparation is as described previously ${ }^{3}$.

Measurements of concentrations of protein by spectrophotometry were based on the following extinction coefficients ${ }^{3}$ : oxidised parsley ferredoxin : $\varepsilon(422 \mathrm{~nm})=9200$, $\varepsilon(465 \mathrm{~nm})=8300$; reduced parsley ferredoxin: $\varepsilon(422 \mathrm{~nm})=4500, \varepsilon(465 \mathrm{~nm})=3600$; oxidised selenium-substituted parsley ferredoxin: $\varepsilon(440 \mathrm{~nm})=9000, \varepsilon(490 \mathrm{~nm})$ $=8 \mathrm{roo}$; reduced selenium-substituted parsley ferredoxin: $\varepsilon(440 \mathrm{~nm})=4200$, $\varepsilon(490 \mathrm{~nm})=3700 \mathrm{l} \cdot \mathrm{mole}^{-1} \cdot \mathrm{cm}^{-1}$.

Anaerobic spectrophotometric titrations of oxidised parsley ferredoxin and oxidised selenium-substituted parsley ferredoxin with NADPH were carried out with the apparatus of Foust et al. ${ }^{8}$, using a catalytic amount of spinach ferredoxinNADP reductase (EC I.6.99.4 $)^{9}$ to mediate the reaction. For these titrations, NADPH (from P and L Biochemicals) was dissolved in o.or M Tris base; its concentration was determined spectrophotometrically using an $\varepsilon(340 \mathrm{~nm})$ of $6200 \mathrm{M}^{-1} \cdot \mathrm{cm}^{-1}$. At the end of each titration, the $\mathrm{pH}$ of the reaction mixture was measured, and then an excess of solid sodium dithionite was added to completely reduce oxidised parsley ferredoxin or oxidised selenium-substituted parsley ferredoxin. The spectrum of the fully reduced material was recorded.

Hydrogenase (EC I.I2.I.I) was purified from crude extracts of Clostridium pasteurianum as described by TAGAWA AND ARNON ${ }^{10}$. The reduction of oxidised parsley ferredoxin and oxidised selenium-substituted parsley ferredoxin by hydrogen and hydrogenase was carried out in stoppered spectrophotometric cuvettes equipped with a side arm. The cuvette contained oxidised parsley ferredoxin or oxidised selenium-substituted parsley ferredoxin in appropriately buffered solution and the side arm contained a small amount of hydrogenase. The cuvette was repeatedly evacuated and filled with hydrogen purified by treatment in a column of copper turnings at $420^{\circ}$. During this process, the cuvette was kept near $0^{\circ}$. After the sixth cycle of evacuation, the cuvette was filled with hydrogen and warmed to $25^{\circ}$. The gas pressure in the cuvette was noted from a manostat in the gas line supplying the hydrogen. The reduction of oxidised parsley ferredoxin or oxidised selenium-substituted parsley ferredoxin was initiated by tipping hydrogenase from the sidearm, and followed to equilibrium by measuring the changes in the visible spectrum. The $\mathrm{pH}$ of the reaction mixture was determined at the end of the experiment.

The results of typical NADPH titrations are shown in Fig. I. At the $\mathrm{pH}$ values for the experiments shown it is clear that a large excess of NADPH causes only a partial reduction of either oxidised parsley ferredoxin or oxidised selenium-substituted parsley ferredoxin. This indicates that the redox potentials for these proteins are substantially below that of the NADPH/NAD ${ }^{+}$couple. The solid lines in the figure are calculated from the equilibrium

$$
\mathrm{NADPH}+2 \mathrm{Fd} \stackrel{\text { ferretoxin-NADP reductase }}{\rightleftharpoons} \mathrm{NADP}^{+}+2 \mathrm{Fd}^{-}+\mathrm{H}^{+}
$$

using $\mathrm{E}_{\mathrm{m} 7}=-0.319 \mathrm{~V}$ (ref. II) for the reduction potential of the NADPH/NADP+ couple, $E_{\mathrm{PFd}^{\star}}=-0.4 \mathrm{I} 6 \mathrm{~V}$ at pH 7.94 and $\mathrm{E}_{\mathrm{SePFd}}{ }^{\star \star}=-0.378 \mathrm{~V}$ at $\mathrm{pH}$ 8.I4. In the case of oxidised selenium-substituted parsley ferredoxin the lag in the titration

* PFd, parsley ferredoxin.

* * SePFd, selenium-substituted parsley ferredoxin. 
suggests the presence of reducible impurities (cf. ref. 12). The amount of $\mathrm{NADP}^{+}$ formed in reducing this material was accounted for in the calculation of the line.

The redox potentials of oxidised parsley ferredoxin and oxidised seleniumsubstituted parsley ferredoxin were also determined by reduction with hydrogen in the presence of hydrogenase, a method first used by TAGAWA AND ARNoNi" to determine the redox potential of spinach ferredoxin. The equilibrium

$$
\mathrm{H}_{2}+2 \mathrm{Fd}=\stackrel{\underline{\text { hydrogenase }}}{=} 2 \mathrm{H}^{+}+2 \mathrm{Fil}^{-}
$$

allows calculation of the redox potential of the ferredoxin. The observed pressure in the vessel minus the tabulated vapor pressure of water was taken as the pressure of hydrogen gas. The results of the NADPH titrations and hydrogen reduction experiments are summarized in Fig. 2 which shows the redox potentials for the two derivatives at various $\mathrm{pH}$ values.

As expected the redox potentials for both proteins are quite low, and there is a slight dependence on $\mathrm{pH}$. The redox potential of oxidised selenium-substituted parsley ferredoxin is some $50 \mathrm{mV}$ higher than that of oxidised parsley ferredoxin. The agreement between the values obtained from hydrogen reduction and NADPH titration is quite good for oxidised parsley ferredoxin, but it is less so for oxidised selenium-substituted parsley ferredoxin. The disparity may be explained by the fact that the selenium derivative is not very stable and it spontaneously decomposes in the presence of oxygen ( $c f$. ref. I3). Even in the absence of oxygen the $\mathrm{pH}$ range in which the protein is moderately stable is much smaller than for oxidised parsley ferredoxin. For example, irreversible changes in the optical spectrum of oxidised selenium-substituted parsley ferredoxin occur above $\mathrm{pH} 8.5$ while that of oxidised parsley ferredoxin is unchanged up to approximately I0.5 (J. A. I $\mathrm{EE}$, unpublished
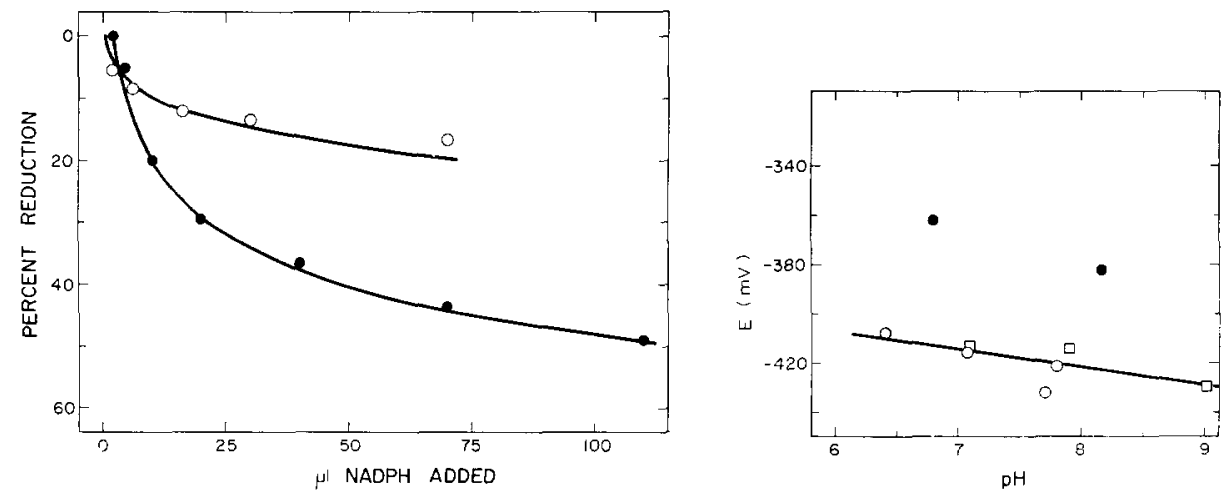

Fig. I. Titration of oxidised parsley ferredoxin ( 0 ) and oxidised selenium-substituted parslev ferredoxin (O) at $\mathrm{pH} 7.94$ and $\mathrm{pH}$ 8. 4 , respectively, with $9 . \mathrm{I} 7 \mathrm{mM} \mathrm{NADPH}$. The anaerobic cuvette contained $2.5 \mathrm{ml}$ o. I M NaCl, o. I M potassium phosphate buffer, I $\mu 1$ o. I $\mathrm{mM}$ ferrecioxin - NADP reductase, and the final concentration of protein in the two experiments was 4.87 .10 is $\mathrm{Noxidised}$ parsley ferredoxin and $4 \cdot 13 \cdot 10^{-5} \mathrm{M}$ oxidised selenium-substituted parsley ferredoxin. The solid lines are calculated from the equilibrium expression (I).

Iig. 2. Summary of redox potentials obtained for oxidised parsley forredoxin by NADPH titration $(\square)$, reduction by hydrogen (O) and for oxidised selenium-substituted parsley ferredoxin obtained by $\mathrm{NADPH}$ titration (O), at various $\mathrm{pH}$ values. 
observations). Its stability under any conditions appears to depend critically on impurities from the reconstitution mixture and products of prior decomposition.

Attempts were made to determine the redox potential difference by titrating mixtures of oxidised parsley ferredoxin and oxidised selenium-substituted parsley ferredoxin with dithionite in the presence of ferredoxin-NADP reductase and recording the circular dichroism spectrum of the system at various stages of reduction. Using the previously published circular dichroism data for the species involved ${ }^{3}$ the circular dichroism spectra of the partially reduced mixtures of proteins were found to be consistent with the Se protein being reduced before the native material, but, due to the slow decomposition of the oxidised selenium-substituted parsley ferredoxin, a quantitative interpretation was not possible.

The oxidation-reduction properties of spinach ferredoxin have been rather extensively explored by a number of workers ( $c f$. ref. I4 for a review). The work of TAGAWA AND ARNON ${ }^{10}$ established the redox potential at $\mathrm{pH} 7.0$ to be $-0.420 \mathrm{~V}$ and to be constant over the $\mathrm{pH}$ range 6.7 and 8.2. Given the great similarity of the spinach and parsley proteins it is not surprising that their redox potentials are identical within experimental error ( $\mathrm{Fig}$. 2). The slight dependence of the potential of oxidised parsley ferredoxin on $\mathrm{pH}$ may reflect small differences in the ionization properties of the oxidized and reduced forms of this protein.

The redox potentials for putidaredoxin and its derivative have been reported ${ }^{15}$ : $E=-0.26 \mathrm{r} \mathrm{V}$ and $-0.245 \mathrm{~V}$ for putidaredoxin and Se-putidaredoxin, respectively, at $\mathrm{pH}$ 8.3. In addition, putidaredoxin shows a decrease in redox potential of about $30 \mathrm{mV} / \mathrm{pH}$ above $\mathrm{pH} 7 \cdot 5$. The difference between the redox potentials of oxidised parsley ferredoxin and oxidised selenium-substituted parsley ferredoxin is much larger than that reported for putidaredoxin but the direction of the change is the same.

There are relatively few reports of the redox potentials of homologous inorganic complexes which contain sulfur or selenium. Thus, there is very little data on which to base any predictions about the effects of substituting selenium for sulfur. However, the increase in polarizability in going from sulfur to selenium suggests there may be a corresponding increase in the stabilization of $\mathrm{Fe}^{2+}$ of reduced selenium-substituted parsley ferredoxin; this possibility is consistent with the observed increase in redox potential which requires that in oxidised selenium-substituted parsley ferredoxin the reduced species is more stable, relative to the oxidized species, than it is in oxidised parsley ferredoxin. The very low redox potentials of this class of proteins, however, has no satisfactory rationalization.

\section{ACKNOWLEDGEMENTS}

This work was supported by National Institutes of Health Research Grants GM I2I76 and GM III06 and National Institutes of Health Computer Grant RR $004 \mathrm{I} 7$.

One of the authors (J.A. F.) is a National Institutes of Health Postdoctoral Trainee.

\section{REFERENCES}

I W. H. Orue-Johnson and H. Beinert, J. Biol. Chem., 244 (Ig69) 6143.

2 W. H. Orme-Johnson And H. Beinert, Biochem. Biophys. Res. Commun., 36 (ig69) 337. 
3 J. A. Fee and G. Palmer, Biochim. Biophys. Acta, 245 (1971) 175.

4 J. Fritz, R. Anderson, J. A. Fee, G. Palmer, R. H. Sands, J. C. Tsibris, I. C. Gunsalis, W. H. Orme-Johnson and H. Beinert, Biochim. Biophys. Acta, in the press.

5 H. Beinert and W. H. Orme-Johnson, Ann. N. Y. Acad. Sci., I 58 (1969) 336.

6 W. H. Orme-Johnson, R. E. Hansen, H. Beinjert, J. C. M. Tsibris, R. C.. Bartholomats and I. C. Gunsalus, Proc. Natl. Acad. Sci. U.S., 60 (I968) 368.

7 J. C. M. Tsibris, R. L. Tsai, I. C. Gunsalus, W. H. Orme-Johnson, R. F. Hansen and H. Beinert, Proc. Natl. Acad. Sci. U.S., 84 (1968) 959.

8 G. P. Foust, B. D. Burleigh, Jr., S. G. Mayhew, C. H. Williams, Jr. ani) V. Massey, Anal. Biochem., 27 (1969) 530.

9 M. Shin, K. Tagawa anj D. I. Arnon, Biochem. Z., 338 (1963) 84.

io K. Tagawa and D. I. Arnon, Biochim. Biophys. Acta. i53 (I968) 602.

I I W. M. ClakK, Oxidation-Reduction Potentials of Organic Systems, Williams and Wilkins, Baltimore, Md., I 960 .

i2 S. G. Mayhew, D. Petering, G. Palmer and G. P. Foust, J. Biol. Chem., 244 (1060) 2830.

i 3 D. Petering, J. A. Fee and G. Palmer, J. Biol. Chem., 246 (I971) 643.

i 4 G. Palmer and H. Brintzinger, in M. Klingenberg and T. King, A Treatise on Electron Transport, Marcel Dekker, New York, N.Y., I97I, in the press.

i 5 G. S. Wilson, in P. Debrunner, J. C. M. Isibris, and E. Münck Mössbauer Spectroscopy in Biological Systems, Univ. Ill. Bull., 67 (1969) 20.

I6 A. Davison and E. T. Shawl, Inorg. Chem., 9 (I970) 1820.

Biochim. Biophys. Acta, 245 (I97I) I96-200 